\title{
Kalmistu kodupaiga sümbolina: Siberi eestlaste näide
}

\author{
Aivar Jürgenson
}

\begin{abstract}
Teesid
Artiklis tuuakse Siberisse väljarännanud eestlaste näitel esile seosed kolme nähtuse - kodupaik, kalmistu ja muld - vahel. Kalmistus ühinevad kodupaiga geograafiline, sotsiaalne ja ajaline mõõde. See on paik, kuhu kuuluvad lahkunud omaksed. Inimene, kes tajub enda ühtekuuluvust omastega, tahab kuuluda nendega kokku ka pärast surma ja seepärast saada maetud nende juurde.

Nii nagu kodupaik on selekteeritud ning kõrgemini väärtustatud lõige maailmast, on seda ka kalmistu. Meie-nemad vastandus ilmneb mõlemas: segarahvastikuga külades elavad inimesed eraldi tänavates või kvartalites ja see eraldatus kandub üle ka kalmistule: kalmistul on sageli igal rahval oma sektor. Üldlevinud tava on olnud haua piiramine aiaga, kuhu pühade ajal sugulased kokku tulevad.

Paikse elanikkonna puhul on tavaline, et inimesed soovivad saada maetud kodukalmistule: sidemeid, mis seovad inimest paigaga eluajal, peetakse tugevamaks surmast. Soov saada maetud kodumaa mulda pole lasknud paljudel lahkuda kodupaigast isegi sõja ajal.

Kodumulda on võõrsile kaasa võetud. See kindlustab võimaluse saada sellesse maetud, st saada oma kultuuris aktsepteeritud matus, mis tagab turvalise ülemineku teispoolsusse. Kodumulda kaasas kandes - selle kohta on erinevatest kultuuridest palju näiteid - kannab inimene kaasas kodumaad ja korrastab seeläbi ümbritsevat võõrast keskkonda. Märksõnad: kalmistu, kalmistukultuur, kodumaa muld, kodupaik, Siberi eestlased.
\end{abstract}

Oluliseks tingimuseks kodupaiga mõiste väljakujunemisel on traditsioonide, ajalise mõõtme olemasolu: kodupaiga kvaliteet sõltub sellest, mida kaugemale minevikku ulatub ajalooline mälu ja mida elavamalt minevik avaldub olevikus, s.t mida intensiivsemalt kogeb inimene kodupaika enda päritolu paigana. Oma küla, seal esivanemate rajatud kodud, sealt lähtuvad teed, põllud ja karjamaad, veskid ja paisjärved, aga ka varasemate põlvkondade poolt väärtustatud traditsioonid kinnistavad kokkukuuluvust mingi konkreetse paigaga, ta praeguste ja endiste elanikega ning tugevdavad identiteeti. Kuna tänast põlvkonda seovad minevikupärandiga esivanemad, on üheks kodupaiga sümboliks ka kalmistu. Siin ühinevad erilise selgusega kodupaiga geograafiline, sotsiaalne ja ajaline mõõde. Inimene, kes tajub ühtekuuluvust omastega, tahab kuuluda nendega kokku ka pärast surma ja seepärast saada maetud nende juurde.

http://haldjas.folklore.ee/tagused/nr25/jyrgenson.pdf 


\section{Aivar Jürgenson}

\section{Kalmistu Siberi eestlastel ning selle territoriaalne liigendus}

Järgnevas vaatleme kalmistu tähendust Siberi eestlastel. Olgu kohe öeldud, et järeldused, mis kehtivad väljarändajate puhul, ei tarvitse samal määral kehtida kompaktselt kindlal territooriumil elava rahva kohta. Paljud kultuurielemendid omandavad diasporaas lisatähenduse, mis neil kodumaal puudub. Nii võivad nad hakata eraldatuse situatsioonis sümboliseerima kaotatud kodumaad. Siberi eestlaste diasporaa on põhiosas kujunenud viimase 150 aasta vältel, hõlmates nii väljasaadetute kui ka vabatahtlike asunike järglasi. Pikkade aastakümnete jooksul on eestlased Siberis elanud suhteliselt tugevas isoleerituses - võõrkeelsetest naabritest on distantseerutud ja see omaetteolemise vajadus ilmneb teatud nähtuste puhul tänagi. Kalmistu pole seejuures erandiks.

Siberi eestlastel kehtib surnuaedadel territoriaalne printsiip - kui külas on mitmest rahvusest elanikke, maetakse surnud eraldi alale, mis kuulub vastavale rahvusele ja/või uskkonnale. Kompaktselt koos elanud rühm kuulub kokku ka pärast surma. Zolotaja Nivas on vasakul luterlaste, paremal õigeusklike hauad,

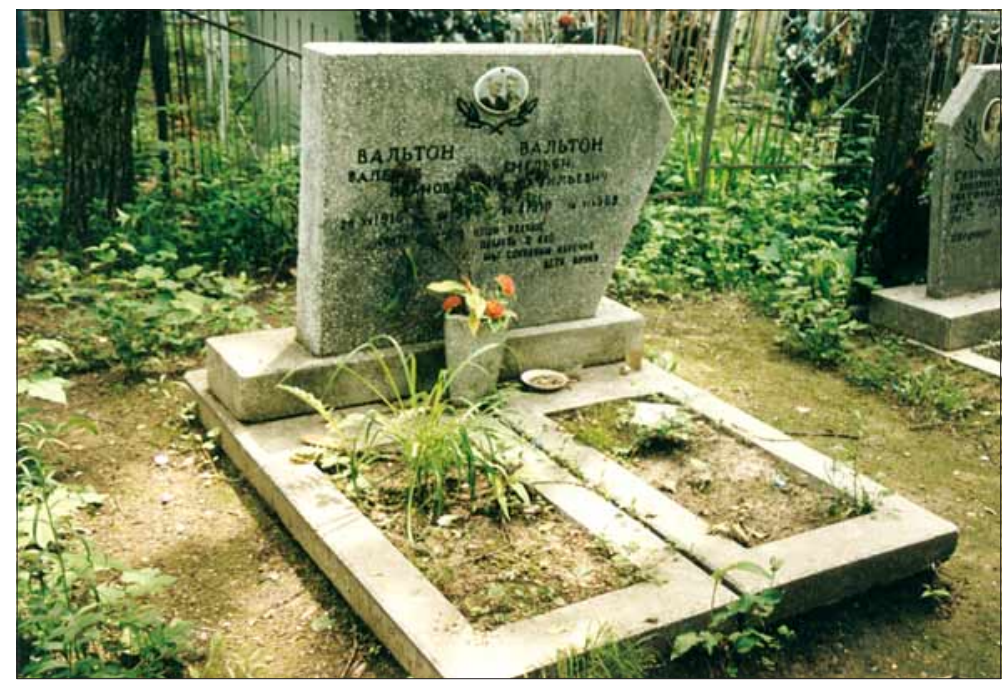

Foto 1. Liiviküla surnuaed Primorje krais. Aivar Jürgensoni foto 2000. 
Uus-Virus maetakse ühele poole eestlased, teisele sakslased, Kovaljovos on eraldi surnuaia osadesse maetud eestlased ja lätlased (Viikberg \& Vaba 1984: 213). Vene külas Motorskis, kus elab arvukalt Ülem-Bulankast pärit eestlasi, on eestlastel surnuaias oma kvartal, sama on lugu Krutoi küla kalmistul. KaugIda Liiviküla surnuaial, mis on ühine naaberkülaga, kehtib samuti territoriaalne printsiip. Surnuaed on paik, kuhu maine elu n-ö suubub - see on paik, mis ulatub igavikku. Kuna maine elu allub reeglitele ja seal valitseb kindel kord, peab kord valitsema ka surnuaial.

Omaette territoriaalse üksuse moodustab hauaplats, kuhu maetakse lahkunud sugulased-hõimlased. Hauaplats on kui kodu, kuhu jõuavad ükskord kokku kõik omaksed - seetõttu on hauaplatsi piiridel tähendus juba siinpoolsuses. Kord käisin koos Karatusis elavate tuttavate eestlastega surnuaiapühal nende omaste hauaplatsil. Hauaplats oli ümbritsetud metalltaraga. Kui hakkasin surnuaialisi pildistama, tahtsid kõik sugulased tingimata kaadris tara sisse mahtuda, väljapoole tara ei soovinud keegi jääda. ${ }^{1}$

Omade kokkukuulumine avaldub surnuaedadel erinevates seostes. Siberi eestlased rõhutavad matmiskommete erinevust venelaste omadest, seda, et neil paikneb rist peatsis, venelastel aga õigeusust tulenevalt jalutsis. Surnuaed on korrastatud paik - vaid see tagab kestvuse, rahu ja harmoonia. Surnuaia väljanägemine on selles seoses oluline. Eestlastele on võõristust tekitanud teiste rahvuste lagedad, puudeta surnuaiad. Reeglid on olulised siinpoolses elus, aga nad "kiirgavad" oma tähendust ka teispoolsusse. Paljudele rahvastele on matmine surnuaia taha, matuse puudumine või näiteks surm võõral maal midagi üheselt halvaendelist. Nii nagu ebaloomulikult surnu muutus vanarahva uskumuste kohaselt kummituseks, ei leidnud rahu pärast surma ka see, kes ei saanud normikohast matust normikohasel surnuaial. On mõistetav, kui Siberisse küüditatutele oli kohati kõige häirivamaks asjaoluks see, et surnud tuli matta justkui karjamaale, "puudeta lagendikule", kus hulguvad lehmad, hobused, sead ja lambad. Eestlased püüdsid haudu siiski tähistada puude, stepi- või põllulillede istutamisega, kusjuures selle poolest erineti teistest Siberi asukatest. Mitmekümne kilomeetri kauguselt käidi haudadele männioksi toomas (Hiiemäe 2000: 128-129).

Siberi eestlased on rääkinud sellest, et haudade kaunistamisel on neil venelastest erinev nägemus: 
Aivar Jürgenson

Surnuaedas tihti käisime. Viisime lillesi ja. Jah. Elavaid lilli - no nü̈̈d on, näe, vene säänesed surnd... need... tehtud lilled. Mis lilled need on?! Me viisime elus lillesi (naine, s 1922, Karatus).

\section{Matus ja surnute mälestamine}

Ka matus ise on rituaal, millel on rühma stabiilsuse seisukohalt oluline tähendus. Rituaal on solidaarsuse väljendus, inimestevahelisi suhteid stabiliseeriv orienteerumisskeem, kogemus kuulumisest, mis rühma ühendab. Üksikisik tajub rituaalis identiteeti (vt Greverus 1987: 258). Siberi eestlased peavad oluliseks eestikeelset matuserituaali. Räägib Ülem-Suetuki naine, kes on oma külas ja naaberkülades surnuid matnud:

Ma olen matnud sada kaks inimest. Ma olen oma emakeeles matnud. Küll ma tahan, et nad mind oma emakeeles mataksivad (naine, s 1921, Ülem-Suetuk).

Jüri Viikberg ja Lembit Vaba vahendavad Siberi eestlaste tava: kui inimene suri mõne sugulase või võõra pool ja surnuaeda minekul jäi kodumaja tee serva, tehti maja ees peatus, mängiti leinamarssi ja siis mindi edasi (Viikberg \& Vaba 1984: 153).

Mitte ainult matusel endal, vaid ka sellele järgnevatel surnu mälestamise rituaalidel on konkreetne funktsioon. Surnu identiteeti tunnustatakse ka pärast surma. Venelaste mõjul on eestlased mitmel pool Siberis hakanud tähistama surnumälestamise päevi üheksandat ja neljakümnendat päeva ning surma-aastapäeva. Nii nagu mitmete teistegi vene kommete ülevõtmist põhjendatakse kohati segaabielude levimisega, on see nii ka surnumälestamisel. Järgnevas katkendis väljendab seda mõtet Ülem-Suetuki naine:

Aivar Jürgenson: A mis siis tehakse, kui nelikümmend sutkit on? - No tahab jälle, et surnuaedas jälle laulda ja olla seal haua juurdes. No nõnna nigu... A ükspäe papp oli külas, ütles, et ära seda mine, et meil lutteri usus seda ei ole. A meil hakkas nü̈̈d venelastega kõik segamini siin. Kes abiellub vene naisega, kes vene mehega ja vat nõnnamoodi siin nigu kõik... hakkavad juba neljakümmend sutkit. Meil enne ei old niukest (naine, s 1921, Ülem-Suetuk). 


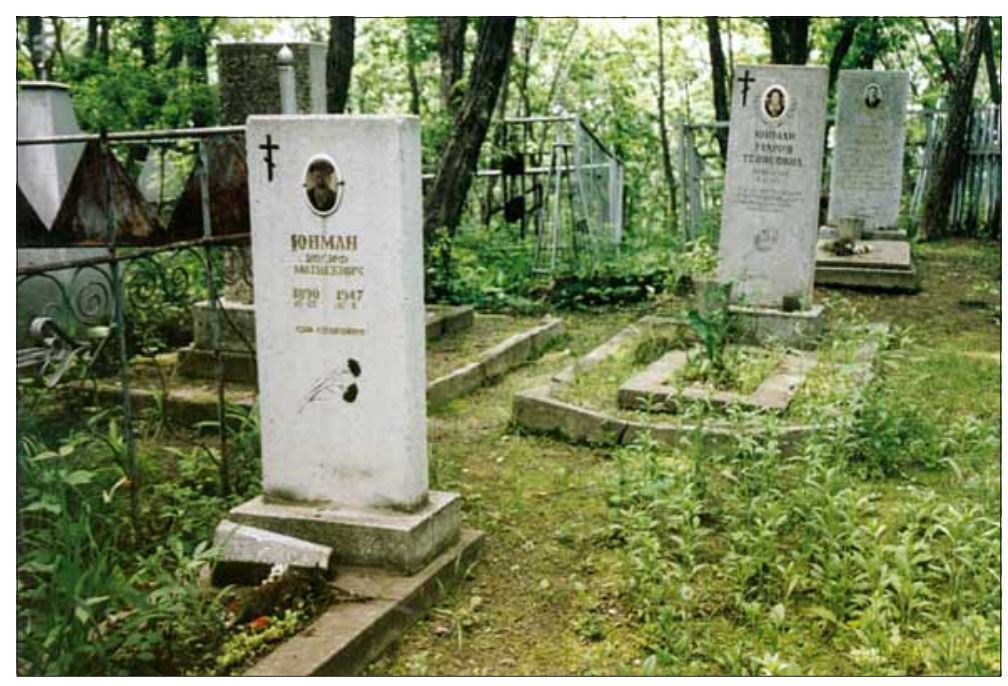

Foto 2. Liiviküla surnuaed Primorje krais. Aivar Jürgensoni foto 2000.

Sidemeid, mis seovad inimest paigaga eluajal, peetakse surmast tugevamaks. Surnuaed vastandub äärmuslikult võõrsile, see on paik, mis seob inimesi kodupaigaga. Näiteid võib tuua erinevatest ajastutest ja erinevatest maadest. Ungarlased, kes jäid Horvaatias 1991. aasta oktoobris sõja jalgu, ei soovinud kodupaigast lahkuda. Üks põhjus oli see, et taheti saada maetud kodumaa mulda (Grafik 1998: 310).

Kui Siberi Vana-Viru küla osale tema elanikest kitsaks jäi, asutati naabrusse uus küla, Uus-Viru. Kuid veel pikka aega matsid sealsedki elanikud oma lahkunuid Vana-Viru kalmistule.

Võõrsil lahkunute ümbersängitamine kodumaa mulda on universaalne tava. Lääne-Austraalia aborigeenide kohta on kirjutatud, kuidas vanade inimeste sooviks on, et neid viidaks sünnipaika, kus nad võiksid surra ja maetud saada (Malmberg 1980: 79, osundatud: Dawson 1881). Egiptusesse eksiili siirdunud Piibli patriarh Jaakob soovis oma säilmete matmist vanemate hauda Tõotatud Maal (1 Mo 47: 29-31). Aga näiteid võib tuua ka lähemalt. 11. augustil 1946 maeti eesti isamaaluule sümbol Lydia Koidula Kroonlinnast ümber Tallinna Metsakalmistule. Soov oma külakalmistule maetud saada on ka Siberi eestlastel tavaline. 
Aivar Jürgenson

Aivar Jürgenson: Kas on neid, kes Suetukist on ära kolinud ja lasevad end matta Suetuki surnuaiale?

- A ükskõik, meie küla inimesed lasevad kõik.

Aivar Jürgenson: Ükskõik, kus nad siis elavad?

- Ja, tulevad ikka toovad siia ligidale. Näe, minu poeg elas ka Taškinas (vene küla) ja... ja iga kord, ikka kui käis meil külas, (ütles) nõnnamoodi, et "minu koht on papa juures". Siis oligi niukene asi, et... et ma pidin ka Taškinasse sinna elama minema ja jääma. Ma ütlen: "Mina tahan ikka oma surnuaeda..." Ärni ütleb, et "no ma tahan ka ju oma surnuaeda jä̈̈da. Ega ma siis sind ei mata nü̈̈d sinna ja siis venelaste hulka, kõik ma toon siia" (naine, s 1921, ÜlemSuetuk).

Sama informant rääkis suure tundepuhanguga enda soovist saada maetud oma surnuaiale:

Irina oli nü̈̈d selle... emadepäeval oli ka külas. Ma ütlen, et tead, kallis laps, ma olen oma kallis külas, ma olen siin sündind ja tahan surra ka siin. Küll on ilus, kui te matate mind oma külas!

\section{Kodumaa muld}

Kodumaa muld võtab vastu oma lahkunud. Kui ärkamisaja luules on sageli juttu sellest, et mullast sünnitakse ja sinna jälle tagasi minnakse, siis on see midagi inimesele ürgselt omast, mitte ainult romantistlik saksalaenuline lahvatus. Kodumaa muld on oluline lüli kodupaiga sümbolite reas. Muld sümboliseerib esmalt maapinda, aga sealt edasi kodumaad üldse. Kui Gustav Wulff-Õie Õrnas ööbikus lauldakse, et vanemate verega on võietud see pind, siis ütleb värsirida, et see on verest läbiimbunud muld. Kui Lydia Koidula, kelle ümbermatmisest rääkisime, laulab veremullast, millest võivad lüüa õitsele lilled (Koidula 1969: 149), siis tähendab see uut algust paljukannatanud maale ja rahvale.

Kodupaiga muld on õieti palju ekspluateerimist leidnud universaalne sümbol, mille sügava tähenduse kohta on teateid erinevatest maailma osadest. Inimene vajab teda selleks, et kindlustada tagasipöördumist, rahus surra, võidelda koduigatsuse vastu vms. 


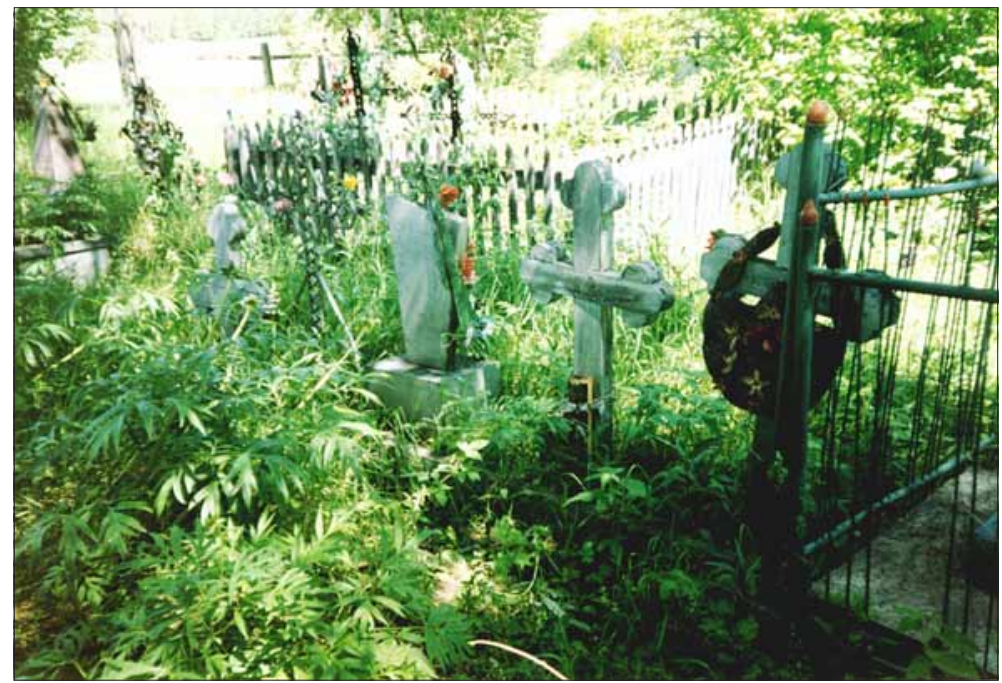

Foto 3. Ülem-Bulanka surnuaed Krasnojarski krais. Aivar Jürgensoni foto 2000 .

Kodumulla võõrsile kaasavõtmine kindlustab võimaluse saada sellesse maetud.

Üks tuntud näide kodumaa-armastusest kui "elementaarsest tundest" on Madagaskari hovad, kes siis, kui nad reisiks valmistusid, väikese tüki oma kodupaiga mulda kaasa võtsid. Teel olles vaatasid nad kodupaiga mulla tükki ja palusid samal ajal oma jumalaid, et nad koju tagasi võiksid jõuda. Koju jõudes viskasid nad kaasavõetud mulla tagasi maapinnale, sinna, kust see oli võetud (Greverus 1972: 205). 1832. aastal võttis Tanamarivo Madagaskarilt kaasa kodupaiga mulda, juudid toovad Palestiina mulda oma surnuaiale, saksa pagendatud võtsid enne lahkumist kodupaigast mulda kaasa (Greverus 1965: 16), mida nad on uues elupaigas tavaliselt auväärses kohas säilitanud, surnutele hauda kaasa pannud, uue põllu mulla sisse seganud, uue maja vundamendi sisse poetanud.

Kodumaa mulla kaasavõtmine ja ohverdamine on pagendatutel mitmete, mitte üksnes religioossete kommete osa. Ta on mälestus kodumaast, jõulukink, auhind võistlustel jne (Schroubek 1968: 281282). Pärast aastakümnetepikkust eemalolekut kodumaad külastavad emigrandid võtavad endise kodupaiga kalmistult mälestuseks mulda (Lehmann 1991: 138). Sõduritele, aga ka teistele kodust saa- 


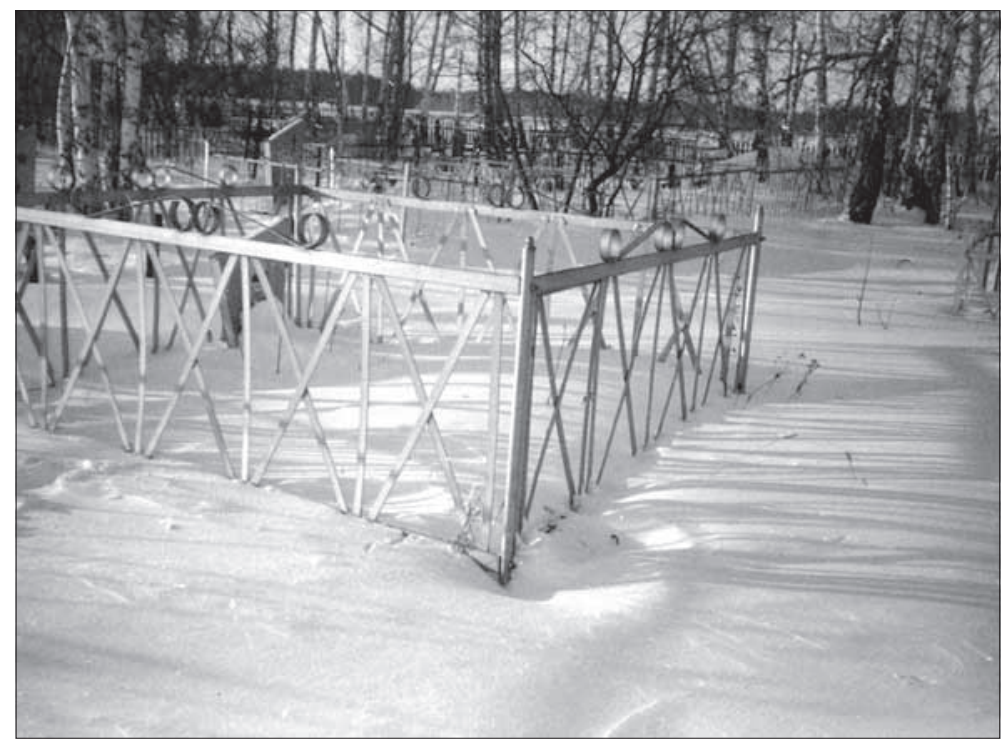

Foto 4. Talvine Vana-Viru küla surnuaed Omski oblastis. Aivar Jürgensoni foto 1996.

tuse sunnil lahkujatele on kodumaa mulda kaasa pandud kaalutlusel, et poeg või tütar on siis kodumaaga "kokku kasvanud", kaitstud ohtude ja koduigatsuse eest. Sõduritele tähendas see ka seda, et surma korral saavad nad maetud koos kodumaa mullaga.

Kodumaa vastandub sümboolsel tasandil võõrsile, nende erinevus on radikaalne: tegemist on üleminekuga ühest elulõigust täiesti teise, tuttavast minevikust tundmatusse tulevikku. Kodumaa mulla kaasavõtmine võib siis olla ka müstiline side minevikuga (Lehmann 1991: 103). Üks eesti naisterahvas, kes käis Siberis küüditamispaigas lähedaste haudu külastamas, kirjutab:

Käisin ka 1989. aastal kalmistul, aga hauakohti ei leidnud. Nelikümmend aastat! Kü̈̈nlad kaasas jäid sü̈̈tamata. Kodukalmistult kaasa võetud mulla puistasin laiali (Hiiemäe 2000: 129).

Või Krasnojarski krai Karatusi rajooni Motorski sovhoosis asumisel olnu: 
Pü̈̈dsime kõike teha nii, nagu meie komme seda nõuab. Puudu jäi peotäis kodumaa mulda (Hiiemäe 2000: 128).

1999. aasta 17. juulil ersa rahva suurkogunemisel Rasjkenj ozks (rahvapalumine), kuhu olid kutsutud osalejad kõikidest ersade elupaikadest, puistasid nad tseremoonia paika kodukalmistult kaasa toodud mulda, millest sai sümboolne Ersa Rahva Kääbas (Lausuja 1999: 2).

Kodumuld ei esine kindlasti alati samas seoses kalmistu mullaga. Paiksele inimesele võib neil kahel olla võrdlemisi erinev tähen-

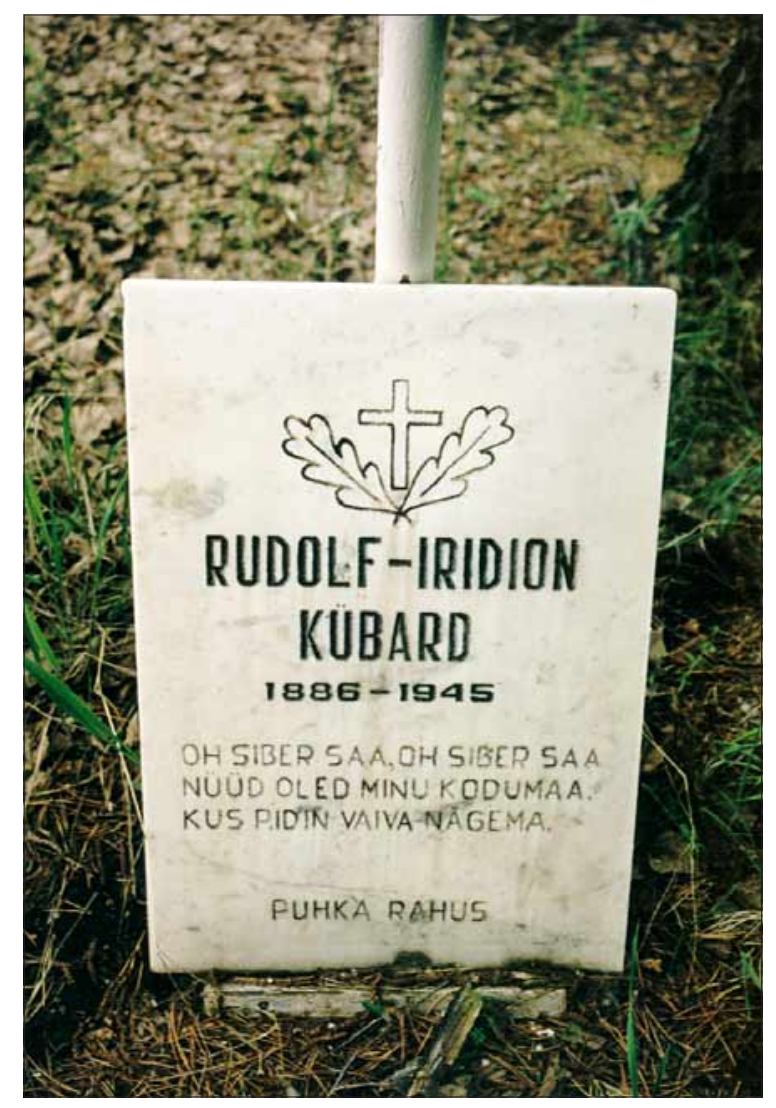

Foto 5. Hauakivi Estonia küla surnuaial Krasnojarski krais. Aivar Jürgensoni foto 2000. 


\section{Aivar Jürgenson}

dus. Siberi eesti asunike seisukohalt on neil kahel sageli aga hoopis tugevam seos. Võimalik, et tegemist on laenuga teiselt rahvusrühmalt, samas ei saa välistada ka võimalust, et kalmistul on väljarändajatele kodupaiga sümbolina suurem kaal kui näiteks Eestis. See kehtib muuseas ka teiste kodupaiga sümbolite kohta, nagu keel või usk (vt Jürgenson 2002).

Igatahes on Siberi eestlased, kes elavad nüüd mujal, kodukalmistu mulda uude elukohta kaasa võtnud. Nii räägiti Ülem-Bulankas sealt pärit ning nüüd Eestis elavatest inimestest:

Näe, Eestimaalt tuli Päärna Liisa siia ja see... Liine. Ja nemad ka... - siin nad sündisivad ja siin nad kasvasivad - ja läksivad Eestisse tagasi, need Päärna Liisa... Ja käisivad surnuaedas ja võtsid omale, viisivad mulda surnuaedast. Ütlesid, et see on me oma kodumaa siin ja ku ma veel viin mulda sinna, ku ükskord me ära sureme, et selle mulla hoiame järel. Ja selle mulla nad panevad nigu... senna auku lasevad ära. Ja viisivad mulda siit. Ega nad palju ei viind, no natukene viisivad. Et see on me oma kodumaa no... muld on. Ja siin on me vanemad siin ja me ise oleme kôik siin sündind ja kasvand äe ja... ja me lapsed on... (naine, s 1926, ÜlemBulanka).

Ka Ülem-Suetukis räägiti inimesest, kes sealt taskurätiku sees kalmistult võetud mulda uude elukohta kaasa viis. Eestis olen rääkinud siin elava Siberi eestlasega, kes samuti on enda sõnul toonud kodukülast - tõsi küll, mitte kalmistult, vaid oma maja juurest mulda Eestisse.

Kodupaiga mulla kaasavõtt aitab korrastada uut ümbrust. Lydia Koidula viis kodumaa mulda Kroonlinna kaasa (Roos 2000: 272) ehk lootis siis temagi oma luules ülistatud isamaad võõrsile kaasa võtta.

Sümboolset sisu võime märgata ka selles, kui maakuulajad, kes käisid Venemaal uusi elupaiku üle vaatamas, tõid kodumaale kaasa sealset mulda (Jääts 1998: 1129) - võime ette kujutada, mida tundsid need inimesed, kes saadikute käest võõra maa mulda peo peale võtsid ja seda sõrmede vahel rutjusid. Maa, see väljarändaja siht ja igatsus, oli ühtäkki sõna otseses mõttes käegakatsutav. Ühele sümboliseerib muld onnnistatud tulevikku, teisele kaotatud minevikku. 


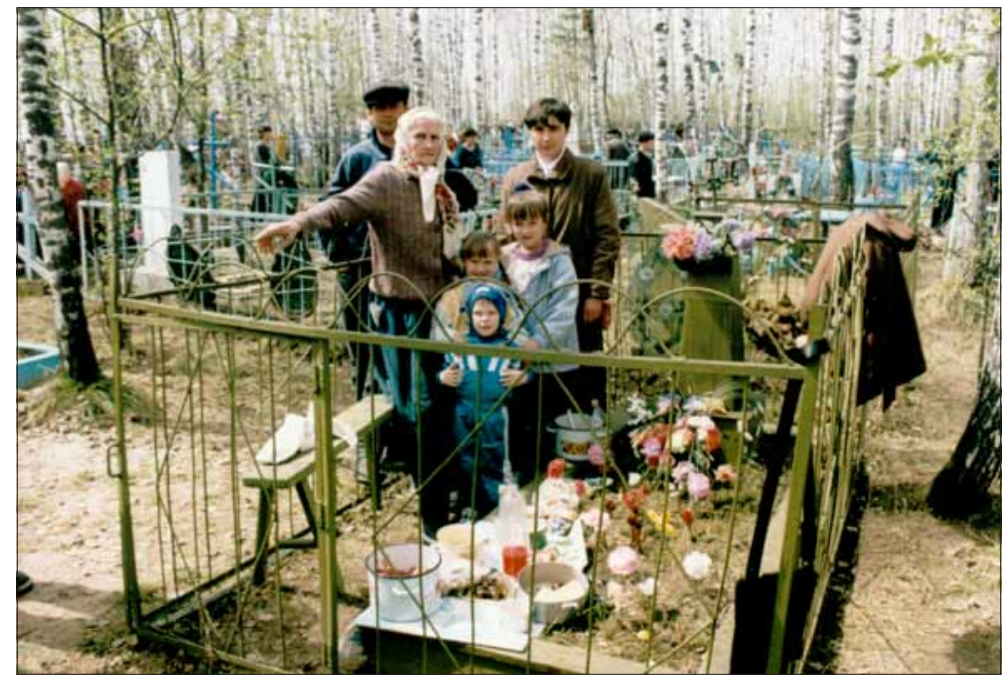

Foto 6. Karatusi surnuaed Krasnojarski krais. Aivar Jürgensoni foto 2000 .

Pühapaikadest mulla kaasavõtmine on palverännus tuntud nähtus nii ristiusulises kui ka eel- ja kristlusevälises ruumis (Schroubek 1968: 281-282). Sellest, et muld on supranormaalsete jõudude hoidja ja andja, annab tunnistust rahvausund. Eesti rahvausundis on surnumatmisliiv tuntud unerohuna, kooljamulla kojutoomine usuti toovat kaasa surnu kodus käima hakkamise (Loorits 1948: 27). Üks naine Krasnojarski krai Estonia külast (s 1927) rääkis, kuidas ta hõõrus isa haualt võetud mullaga käsi, kui need valutasid, ning valu läks üle. Mitmed seosed viitavad sellele, millist tähendust on inimene läbi ajaloo mullale omistanud.

Kodupaik, pühapaik ja muld - selles semantilises kompleksis täiendab üks element teist ja viitab universaalsete väärtuste kaanonile, mis nii ajalises kui ka ruumilises mõõtmes moodustavad orgaanilise terviku.

Tiiu Jaago kirjeldab, kuidas üks põline virulane, kes oli aastatel 1945-1957 küüditatuna Siberis, rõõmustas, et ta ohuaegadel Eestist välja ei rännanud, sest temal on võimalus saada maetud sinna, kus on tema koht - Jõhvi vanasse surnuaeda. T. Jaago esitab küsimuse: 


\section{Aivar Jürgenson}

Kas see - saada maetud sinna, kus on sinu koht - on midagi niisugust, mis tuleb inimese juurde hiljem, teatud vanuses? Taas üks väljendusviise, kuidas väärtustatakse kokkukuulumist esivanemate, oma koha (maamulla) ja järjepidevusega (Jaago 2000: 179).

Oma maa seotakse inimeste teadvuses üpris vahetult surnuaiaga. Kui ka elatakse pikema või lühema aja vältel võõrsil, on oma maa ajatu ja seda ajatust sümboliseerib surnuaed. Paiga ja mulla seostamine tuleb justkui iseenesest. Siin ei ole tegu üksnes sellega, et muld sümboliseerib maad. Seos on, võib-olla küll kaudsemalt, olemas teiseski mõttes. Oma paik - see on korrastatud lõige maailmast, oma korrastatuses turva pakkuv, paik, milles on võimalik end ajavoolus paremini fikseerida. Paik, kus igasugused arengud on paremini prognoositavad ja osalt ka juhitavad. See prognoositavus seobki teda mullaga - märkamaks, et mullast sünnib uus elu ja et mulda hääbub kõik, mis on elus, ei ole tarvis olla põlluharija. Neandertallasest kütile keskmises paleoliitikumis oli see sama mõistetav kui 19. sajandi talupojale. See reeglipärasus annab mullale tähenduse, mis sümboliseerib stabiilsust. Paralleelid on selged: oma paik on stabiilne lõige maailmast, mis vastandub heitlikule piiridetagusele alale, siin on võimalik oodata asju, mida ennegi nähtud, siin on võimalik loota - muld on stabiilne keskkond heitliku maailma varjus. Tuttavad on mulla toime ja käitumine. Tuttav nagu kodupaik.

Järeldus, milleni siit jõuame - surnuaed on sümboolsel tasandil kodu vaste - , ei ole uus. Hauakambrid, majakujulised sarkofaagid ja urnid - eelkirjeldatud seoseid kodu ja surnuaia vahel on jäädvustanud paljud muistsed rahvad, ja nagu eelnevalt nägime, leiavad need jätkuvalt manifesteerumist tänase päevani.

\section{Kommentaar}

${ }^{1} \mathrm{Ka}$ näiteks Skandinaavia maades on olnud üldlevinud tava piirata hauad aiaga, kuhu pühade ajal sugulased kokku tulevad (Malmberg 1980: 201). 
Aivar Jürgenson

\section{Kirjandus}

Grafik, Imre 1998. Nation, Nationality, National Minority. Acta Ethnographica Hungarica 43: 3-4, lk 307-325.

Greverus, Ina-Maria 1965. Heimweh und Tradition. Schweizerisches Archiv für Volkskunde 61, lk 1-31.

Greverus, Ina-Maria 1972. Der territoriale Mensch: Ein literaturanthropologischer Versuch zum Heimatphänomen. Frankfurt am Main: Athenäum.

Greverus, Ina-Maria 1987. Kultur und Alltagswelt: Eine Einführung in Fragen der Kulturanthropologie. Notizen / Institut für Kulturanthropologie und Europäische Ethnologie, Frankfurt am Main 26. Frankfurt am Main: Institut für Kulturanthropologie und Europäische Ethnologie der Universität.

Hiiemäe, Mall 2000. Küüditatuna Siberis. Aivar Jürgenson (koost ja toim). Eestlane ja tema maa: Konverentsi "Kodumaa ja kodupaik: eestlase territoriaalne identiteet” (16.-17. november 1999, [Tallinn]) materjale. Scripta ethnologica 4. Tallinn: Ajaloo Instituut, lk 122-139.

Jaago, Tiiu 2000. "Esiisa tuli..." Kodukoha mõiste päritolujutustustes. Aivar Jürgenson (koost ja toim). Eestlane ja tema maa: Konverentsi "Kodumaa ja kodupaik: eestlase territoriaalne identiteet" (16.-17. november 1999, [Tallinn]) materjale. Scripta ethnologica 4. Tallinn: Ajaloo Instituut, lk 168-183.

Jääts, Indrek 1998. Setude etniline identiteet: With summary in English "The Ethnic Identity of the Setus". Studia ethnologica Tartuensia 1. Tartu: Tartu Ülikooli Kirjastus.

Jürgenson, Aivar 2002. Siberi eestlaste territoriaalsus ja identiteet. Tallinn: Tallinna Pedagoogikaülikooli Kirjastus.

Koidula, Lydia 1969. Luuletused: Tekstikriitiline väljaanne. Eva Aaver (toim). Tallinn: Eesti Raamat.

Lausuja 1999. 1999. aasta 17. juuli Rasjkenj ozks (rahvapalumine) Ersamaal ja Järvamaal. Fenno-Ugria infoleht 3 (19), oktoober, lk 1-2.

Lehmann, Albrecht 1991. Im Fremden ungewollt zuhaus. Flüchtlinge und Vertriebene im Westdeutschland 1945-1990. München: Verlag C. H. Beck.

Loorits, Oskar 1948. Eesti rahvausundi maailmavaade. Stockholm: Eesti Raamat.

Malmberg, Torsten 1980. Human territoriality: Survey of behavioural territories in man with preliminary analysis and discussion of meaning. New Babylon, studies in the social sciences 33 The Hague \& New York: Mouton. 


\section{Aivar Jürgenson}

Roos, Aarand 2000. Pagulaste missioon. Aivar Jürgenson (koost ja toim). Eestlane ja tema maa: Konverentsi "Kodumaa ja kodupaik: eestlase territoriaalne identiteet" (16.-17. november 1999, [Tallinn]) materjale. Tallinn: Ajaloo Instituut, lk 89-96.

Schroubek, Georg R. 1968. Wallfahrt und Heimatverlust. Ein Beitrag zur religiösen Volkskunde der Gegenwart. Schriftenreihe der Kommission für Ostdeutsche Volkskunde in der Deutschen Gesellschaft für Volkskunde e.V. 5 Marburg: N.G.Elwert Verlag.

Viikberg, Jüri \& Vaba, Lembit 1984. Siberi põhjaeestlasi kõnetamas III. Keel ja Kirjandus 3, lk 145-156; 4, lk 210-223. 